\title{
Enhanced Functionalities of Whey Proteins Treated with Supercritical Carbon Dioxide
}

\author{
Q. Zhong ${ }^{1}$ and M. Jin \\ Department of Food Science and Technology, University of Tennessee, Knoxville 37996
}

\begin{abstract}
The functionality of whey proteins can be modified by many approaches; for example, via complexation with carbohydrates, enzymatic cross-linking, or hydrolysis, and the objective of this work was to research the effects of supercritical carbon dioxide $\left(\mathrm{scCO}_{2}\right)$ treatments on the functionalities of commercial whey protein products including whey protein isolates (WPI) and whey protein concentrates (WPC). The WPI and WPC powders and a $10 \%$ (wt/vol) WPI solution were treated with $\mathrm{scCO}_{2}$. The WPI solution was treated at $40^{\circ} \mathrm{C}$ and $10 \mathrm{MPa}$ for $1 \mathrm{~h}$, whereas WPI and WPC powders were treated with $\mathrm{scCO}_{2}$ at $65^{\circ} \mathrm{C}$ and 10 or $30 \mathrm{MPa}$ for $1 \mathrm{~h}$. Dynamic rheological tests were used to characterize gelation properties before and after processing. Compared with the unprocessed samples and samples processed with $\mathrm{N}_{2}$ under similar conditions, $\mathrm{scCO}_{2}$-treated WPI, whether dispersed in water or in the powder form during treatments, formed a gel with increased strength. The improvement in gelling properties was more significant for the $\mathrm{scCO}_{2}$-treated WPC. In addition, the $\mathrm{scCO}_{2}$-processed WPI and WPC powders appeared to be fine and free-flowing, in contrast to the clumps in the unprocessed samples. Proximate compositional and surface hydrophobicity analyses indicated that both compositional and structural changes may have contributed to enhanced whey protein functionalities. The results suggest that functionalities of whey proteins can be improved by $\mathrm{scCO}_{2}$ treatment to produce novel ingredients.
\end{abstract}

Key words: whey protein, supercritical carbon dioxide, functionality, rheology

\section{INTRODUCTION}

Whey proteins have been studied extensively because of their widespread use as nutritious, highly functional but affordable food ingredients. Depending on the sepa-

Received September 3, 2007.

Accepted October 23, 2007.

${ }^{1}$ Corresponding author: qzhong@utk.edu ration processes used to extract proteins, variations in product compositions can be obtained. Whey protein concentrates (WPC) are commercial products with a protein content of 25 to $80 \%$, whereas whey protein isolates (WPI) usually have more than $90 \%$ protein (Foegeding et al., 2002). Variations in the composition and preparation methods significantly change protein functionality (Damodaran, 1997; van Vliet et al., 2002).

Protein functionality is a general term used to describe any function a protein provides: solubility, waterholding capacity, structure formation in dairy and meat products, the ability to form and stabilize oil-water (in emulsions) and air-water (in foams) interfaces, and the ability to remain in suspension during thermal processing among others (Foegeding et al., 2002). Functional properties of protein ingredients are affected by factors such as origin, preparation method (which leads to different compositions and structure changes), physiochemical properties of the systems in which proteins are incorporated, and storage conditions (van Vliet et al., 2002; Baier and McClements, 2005).

Approaches to modifying protein functionality include complexation with carbohydrates via physical (noncovalent) or chemical (covalent) bonds to enhance functionalities such as interfacial activity (Dickinson and Galazka, 1991; Dickinson and Semenova, 1992), cross-linking (via thermal aggregation or enzymatic reaction), and hydrolysis (Foegeding et al., 2002). When modifying protein functionality, however, attention must be paid to regulations that may limit the application of these modified products as ingredients in foods (McClements, 2005).

Modifying protein functionality with physical methods may encounter fewer regulatory hurdles. High hydrostatic or dynamic pressure has been investigated as a physical method to modify whey and soy protein functionality. The irreversible change in structure needed to alter protein functionality of $\alpha$-LA, $\beta$-LG, and glycinin occurs above 400,150 , and $400 \mathrm{MPa}$, respectively (Tanaka et al., 1996a,b; Tanaka and Kunugi, 1996; Molina et al., 2001).

Supercritical carbon dioxide $\left(\mathbf{s c C O}_{2}\right)$ may be a more practical and affordable approach to modifying protein 
functionalities, a fact that has been exemplified by the commercial production of decaffeinated coffee. Carbon dioxide has also been used as a weak acid to precipitate milk and soy proteins dispersed in aqueous solutions (Tomasula et al., 1997, 1998; Strange et al., 1998; Hofland et al., 1999; Thiering et al., 2001a,b; Tomasula and Yee, 2001). For the case of whey proteins, separation of WPC dispersions into $\alpha$-albumin-rich or $\beta$-LGrich fractions can be achieved by manipulating precipitation conditions (Tomasula et al., 1998; Tomasula and Yee, 2001). Compared with a reference WPC solution, the fractionated $\beta$-LG-rich fraction enhanced interfacial activity and thickening and gelling properties (Tomasula and Yee, 2001). Another technique of supercritical fluid extrusion has been developed to process foods with novel functionalities properties (Alavi et al., 1999; Gogoi et al., 2000).

Thermodynamically, $\mathrm{scCO}_{2}$ has a liquid-like density and gas-like diffusivity and viscosity ( $\mathrm{McHugh}$ and Krukonis, 1994). Supercritical conditions of $\mathrm{CO}_{2}$ are relatively easy to achieve (critical temperature of $31.1^{\circ} \mathrm{C}$ and critical pressure of $7.38 \mathrm{MPa}$ ). Further, $\mathrm{CO}_{2}$ is an environmentally friendly solvent that is ideal for food processing. It is inflammable, nontoxic, chemically inert, physiologically safe, and can be easily recycled and reused. Further, $\mathrm{scCO}_{2}$ has a surface tension of zero (McHugh and Krukonis, 1994), which leads to complete and rapid wetting, thus allowing penetration of complex structures (Zhang et al., 2006). The $\mathrm{scCO}_{2}$ can be used to extract lipids and other nonpolar and polar (with a cosolvent such as ethanol) compounds in commercial whey protein ingredients and cause direct changes in compositions. Protein structures may also change due to the depletion or redistribution of nonpolar compounds. These aspects may introduce novel protein functionalities.

The objective of this work was thus to evaluate the functionalities of whey proteins before and after $\mathrm{scCO}_{2}$ processing, with a focus on gelation properties. Gelation of whey proteins has been studied extensively at various solvent conditions. $\mathrm{pH}$ values of 3.35 and 7.0 were selected as representive conditions below and above the isoelectric point of whey proteins, respectively; both $\mathrm{pH}$ values have been used to evaluate gelation properties of whey protein ingredients (Ikeda et al., 1999; Resch et al., 2005). The outcome of this work may lead to specialized ingredients of novel applications.

\section{MATERIALS AND METHODS}

\section{Materials}

A WPC $80 \%$ sample and a WPI sample were kindly supplied by Davisco Foods International Inc. (Eden Prairie, MN). Samples were stored at $-20^{\circ} \mathrm{C}$ upon ar-

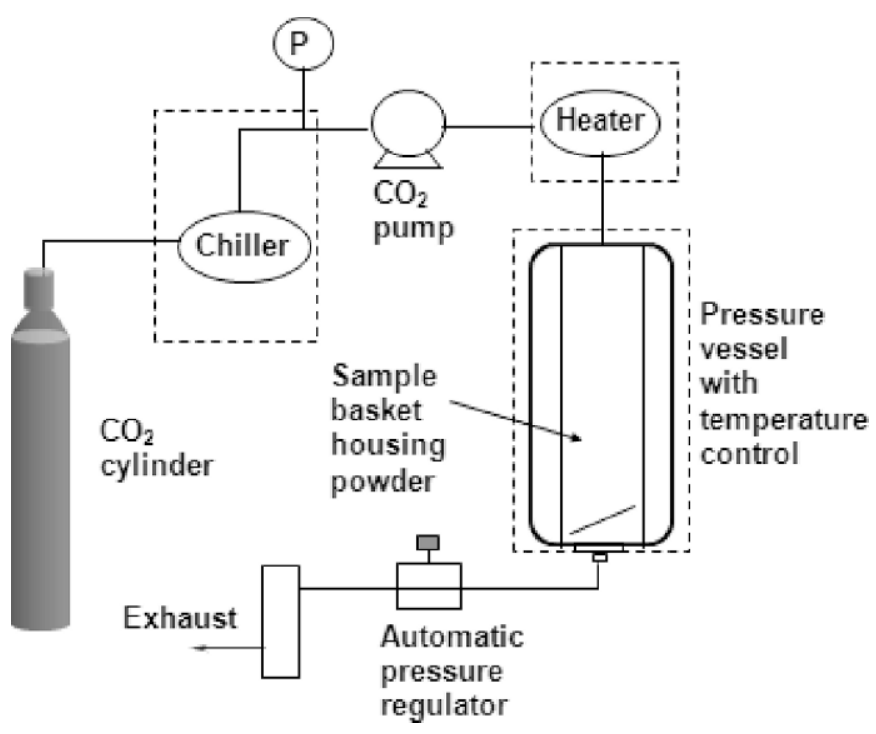

Figure 1. Schematic of the supercritical $\mathrm{CO}_{2}$ system.

rival and used directly without further purification. All processed and unprocessed powder samples were analyzed for total protein (AOAC, 1990; method 984.13), lipids (AOAC, 1990; method 948.15), and moisture (AOAC, 1990; method 950.46) contents by ABC Research Corporation (Gainesville, FL). Duplicate tests were done for protein and moisture contents, but only one test was performed for the total lipids content because of the insufficiency of sample quantities from the same batch treatment.

\section{Equipment and Processing Protocols}

The $\mathrm{scCO}_{2}$ system (model SAS50, Thar Technologies, Pittsburgh, PA) is illustrated schematically in Figure 1. Bone-dry grade $\mathrm{CO}_{2}$ (Airgas, Chicago, IL) from a cylinder was cooled to $3^{\circ} \mathrm{C}$ by a heat exchanger and delivered by a $\mathrm{CO}_{2}$ pump continuously at a controlled mass flow rate. The $\mathrm{CO}_{2}$ was heated to a set temperature by another heat exchanger before entering the pressure vessel (500-mL volume). The vessel pressure was regulated by an automatic pressure regulator downstream, and the vessel temperature was controlled by an outer heat jacket.

In a typical experiment, $25 \mathrm{~g}$ of WPI or WPC powder was contained in a sample basket with a 5 - $\mu \mathrm{m}$ frit at the bottom, which was then placed into the pressure vessel. The pressure vessel cap was then closed, and the valve to the $\mathrm{CO}_{2}$ cylinder was opened. All processing parameters were controlled by computer. A treatment time was defined as that after the system reached the set pressure and temperature (in about $5 \mathrm{~min}$ ). After $1 \mathrm{~h}$ treatment with $\mathrm{CO}_{2}$ at a mass flow rate of $50 \mathrm{~g} /$ 
min, the vessel was depressurized in about $15 \mathrm{~min}$ and the sample was collected and stored at $-20^{\circ} \mathrm{C}$ before rheological tests. In another set of experiments, the sample basket was replaced by an open-top stainless steel container with a similar diameter, filled with 100 $\mathrm{mL}$ of a $10 \%$ (wt/vol in deionized water without $\mathrm{pH}$ adjustment) WPI solution and processed with $\mathrm{scCO}_{2}$ as above. A control was processed similarly with compressed nitrogen $\left(\mathrm{N}_{2}\right)$ for both WPI powders and a $10 \%$ (wt/vol) WPI solution.

Because BSA shows partial, reversible unfolding between 42 and $50^{\circ} \mathrm{C}$ (Lin and Koenig, 1976), a temperature of $40^{\circ} \mathrm{C}$ was chosen for the WPI solution treatments to single out the $\mathrm{scCO}_{2}$ effects from the thermal denaturation of proteins. On the other hand, because a higher temperature facilitates the extraction of lipids from powder samples (Froning et al., 1990; Manganiello et al., 2000; Wolf et al., 2003), a temperature of $65^{\circ} \mathrm{C}$ was selected, while keeping the temperature below the denaturation temperatures of $\alpha$-LA $\left(67.1^{\circ} \mathrm{C}\right)$ and $\beta$-LG (76.3 ${ }^{\circ} \mathrm{C}$; Ju et al., 1999), the 2 major whey proteins.

\section{Rheological Tests}

Sample Preparation. Five grams of WPC or WPI powder was hydrated in $50 \mathrm{~mL}$ of deionized water overnight at room temperature. Then, the $\mathrm{pH}$ was adjusted to 3.35 or 7.0 with $1 \mathrm{~N} \mathrm{HCl}$ or $1 N \mathrm{NaOH}$. The final powder concentration was $9.9 \%$ (wt/vol) at $\mathrm{pH} 7.0$ and 9.4\% (wt/vol) at $\mathrm{pH} 3.35$. The $\mathrm{pH} 7.0$ samples also contained $100 \mathrm{~m} M \mathrm{NaCl}$. The $\mathrm{scCO}_{2}$-processed $10 \%$ WPI solution had a $\mathrm{pH}$ of 5.80 after opening the vessel (a time lag of approximately 30 min after stopping the $\mathrm{CO}_{2}$ stream, much slower depressurization than processing powders to prevent extensive foaming) and some protein precipitated (due to acidification). The suspension was continuously stirred overnight at room temperature to deplete the dissolved $\mathrm{CO}_{2}$ and dissolve the precipitate. The stirred solution recorded no difference in $\mathrm{pH}(\mathrm{pH}=6.75)$ from the unprocessed sample before $\mathrm{pH}$ adjustment and was then adjusted to $\mathrm{pH} 3.35$ with 1 $N$ HCl. The solubility of $\mathrm{N}_{2}$ in water is low, and the WPI solution processed by $\mathrm{N}_{2}$ did not have the foaming issue and recorded no $\mathrm{pH}$ change. The $\mathrm{pH}$ adjustment to 3.35 was therefore done shortly after processing. The amount of $1 \mathrm{~N} \mathrm{HCl}$ used to adjust $\mathrm{pH}$ to 3.35 was identical for the unprocessed WPI solution and the solutions processed by $\mathrm{CO}_{2}$ and $\mathrm{N}_{2}$.

Rheological Test Procedures. Dynamic rheological tests were performed with an AR2000 rheometer (TA Instruments, New Castle, DE) using a Searle set up (bob, outside diameter $=28 \mathrm{~mm}$ and cup, inside diameter $=30 \mathrm{~mm}$ ). After positioning the bob and removing the excess sample, a layer of mineral oil was applied on top of the sample, and a sealing cap was used to minimize moisture loss during measurements. A $1 \%$ strain amplitude (within the linear viscoelasticity regimen) was used for the following steps: 1) a linear heating step from 20 to $90^{\circ} \mathrm{C}$ at $1^{\circ} \mathrm{C} / \mathrm{min}, 2$ ) an isothermal step at $90^{\circ} \mathrm{C}$ for $3 \mathrm{~h}, 3$ ) a frequency sweep step from 0.01 to $10 \mathrm{~Hz}$ at $\left.90^{\circ} \mathrm{C}, 4\right)$ a linear cooling step from 90 to $20^{\circ} \mathrm{C}$ at $1^{\circ} \mathrm{C} / \mathrm{min}$, and 5) a frequency sweep step from 0.01 to $10 \mathrm{~Hz}$ at $20^{\circ} \mathrm{C}$. The oscillation frequency during steps 1, 2, and 4 was $1 \mathrm{~Hz}$. Triplicate tests were performed for each sample.

\section{Surface Hydrophobicity of Proteins}

Salting-out properties of WPI were used as an indirect measurement of relative protein surface hydrophobicity (Lindahl et al., 1981). Different concentrations of ammonium sulfate, $\left(\mathrm{NH}_{4}\right)_{2} \mathrm{SO}_{4}$ (0 to $3.465 \mathrm{M}$, $\mathrm{pH}$ 3.35) were prepared by mixing different proportions of a $\left(\mathrm{NH}_{4}\right)_{2} \mathrm{SO}_{4}$ stock solution (3.465 $M$ in $20 \mathrm{mM}$ sodium phosphate, adjusted to $\mathrm{pH} 3.35$ ) and a $20 \mathrm{mM}$ sodium phosphate solution ( $\mathrm{pH}$ 3.35). The $\left(\mathrm{NH}_{4}\right)_{2} \mathrm{SO}_{4}$ solution $(990 \mu \mathrm{L})$ was mixed with $10 \mu \mathrm{L}$ of the WPI pH 3.35 samples (the unheated leftover from rheological tests), and the mixture was continuously agitated for $30 \mathrm{~min}$ on an end-to-end shaker (Lab Industries Inc., Berkeley, CA) at room temperature. The suspension was then centrifuged at $14,500 \times g$ for $15 \mathrm{~min}$ (MiniSpin Personal, Eppendorf, Westbury, NY). The supernatant was analyzed for the total protein concentration by the Bradford method (Bradford, 1976) using an assay kit containing Coomassie (Bradford) reagent and BSA standard from Pierce Biotechnology (Rockford, IL). All samples were measured in triplicate; results, in averages and $95 \%$ confidence intervals, were reported by normalizing to the corresponding sample protein concentration at 0 $M\left(\mathrm{NH}_{4}\right)_{2} \mathrm{SO}_{4}$.

\section{Scanning Electron Microscopy}

The scanning electron microscopy tests were performed with a LEO 1525 SEM microscope (LEO Electron Microscopy, Oberkochen, Germany) for WPI and WPC powder samples before and after processing. The powder sample was glued directly onto an adhesive tab mounted on the specimen stub and sputter-coated with a thin layer of gold $(\sim 5 \mathrm{~nm})$.

\section{Statistical Analysis}

An ANOVA was used to evaluate the compositional and rheological data; the Tukey test was performed with the assistance of JMP software (version 6.0, SAS Institute, Cary, NC). However, statistical analysis was 
Table 1. Sample compositions of whey protein concentrate (WPC) and whey protein isolate (WPI) powders ${ }^{1}$ unprocessed and processed with supercritical $\mathrm{CO}_{2}\left(\mathrm{scCO}_{2}\right)$ or $\mathrm{N}_{2}$

\begin{tabular}{|c|c|c|c|c|c|}
\hline \multirow[b]{2}{*}{ Sample } & \multirow[b]{2}{*}{$\begin{array}{c}\text { Temperature } \\
\left({ }^{\circ} \mathrm{C}\right)\end{array}$} & \multirow[b]{2}{*}{$\begin{array}{l}\text { Pressure } \\
(\mathrm{MPa})\end{array}$} & \multicolumn{3}{|c|}{ Composition } \\
\hline & & & $\begin{array}{l}\text { Protein }^{1} \\
(\%)\end{array}$ & $\begin{array}{c}\operatorname{Lipids}^{2} \\
(\%)\end{array}$ & $\begin{array}{l}\text { Moisture }^{1} \\
(\%)\end{array}$ \\
\hline Unprocessed WPI & - & - & $91.21 \pm 0.16^{\mathrm{b}}$ & 0.13 & $5.93 \pm 0.17^{\mathrm{a}}$ \\
\hline $\mathrm{scCO}_{2}$-processed WPI & 65 & 10 & $92.27 \pm 0.13^{\mathrm{a}}$ & 0.11 & $5.17 \pm 0.08^{\mathrm{ab}}$ \\
\hline $\mathrm{scCO}_{2}$-processed WPI & 65 & 30 & $92.71 \pm 0.01^{\mathrm{a}}$ & 0.05 & $4.41 \pm 0.29^{\mathrm{bc}}$ \\
\hline $\mathrm{N}_{2}$-processed WPI & 65 & 10 & $90.48 \pm 0.19^{b}$ & 0.21 & $5.80 \pm 0.23^{\mathrm{a}}$ \\
\hline Unprocessed WPC & - & - & $75.46 \pm 0.21^{\mathrm{e}}$ & 7.16 & $4.44 \pm 0.46^{\mathrm{bc}}$ \\
\hline $\mathrm{scCO}_{2}$-processed WPC & 65 & 10 & $76.63 \pm 0.15^{\mathrm{d}}$ & 7.74 & $3.51 \pm 0.12^{\mathrm{c}}$ \\
\hline $\mathrm{scCO}_{2}$-processed WPC & 65 & 30 & $78.58 \pm 0.44^{\mathrm{c}}$ & 6.41 & $3.53 \pm 0.28^{\mathrm{c}}$ \\
\hline
\end{tabular}

${ }^{\mathrm{a}-\mathrm{e}}$ Means with a different letter in each column are statistically different.

${ }^{1}$ Values are averages \pm standard deviations from 2 tests.

${ }^{2}$ Only 1 replicate was performed, as explained in the Materials and Methods section.

not performed for the lipids content because only one test was done for each sample.

\section{RESULTS AND DISCUSSION}

\section{Sample Compositions}

Proximate composition analyses of WPI and WPC powders before and after processing are listed in Table 1. The measured compositions of the unprocessed WPI sample were similar to the product label that listed $92.7 \%$ protein, $0.3 \%$ fat, and $5.0 \%$ moisture. The moisture content of WPI powders decreased slightly after $\mathrm{scCO}_{2}$ processing, and the decrease was more significant for the $30 \mathrm{MPa}$ treatment than for the $10 \mathrm{MPa}$ treatment. Also decreased was the lipid content, which was expected from the well-known capability of $\mathrm{scCO}_{2}$ to extract lipids. The protein content per unit mass of powders was statistically greater for the $\mathrm{scCO}_{2}$-processed samples. In contrast, there was no significant difference in moisture and protein contents between the unprocessed sample and that treated with $\mathrm{N}_{2}$. These data indicate that $\mathrm{scCO}_{2}$, because of zero surface tension, had much better penetration capability than $\mathrm{N}_{2}$ at similar temperatures and pressures, which increased the rate of moisture and lipids transportation out of protein powder granules.

For WPC, the measured compositions of unprocessed WPC sample were also similar to the labeled $78.0 \%$ protein, $8.0 \%$ fat, and $4.5 \%$ moisture. In comparison, reduced moisture content was recorded for the $\mathrm{scCO}_{2}$ treated samples. The lipids content after the $10 \mathrm{MPa}$ treatment was similar to that in the unprocessed samples, possibly due to the inefficiency of the $\mathrm{CO}_{2}$ extraction at this pressure. Conversely, the sample after the $30 \mathrm{MPa}$ treatment had a lower lipid content. The protein content significantly increased after the $\mathrm{scCO}_{2}$ extraction.

\section{Sample Appearance and Notable Sensory Changes}

Visual appearance of processed and unprocessed whey protein powder samples is presented in Figure 2. The unprocessed WPI (panel A) and that processed by $\mathrm{N}_{2}$ (panel D) had loose clumps and did not move freely, whereas those processed by $\mathrm{scCO}_{2}$ appeared as fine powders (panels B and C). Similarly, the unprocessed WPC had many clumps (panel E) that still existed after being processed by $\mathrm{scCO}_{2}$ at $65^{\circ} \mathrm{C}$ and $10 \mathrm{MPa}$ (panel F); but no more clumps were observed after processing with $\mathrm{scCO}_{2}$ at $65^{\circ} \mathrm{C}$ and $30 \mathrm{MPa}$ (panel G). The changes in lipid content (Table 1), although lacking statistical support, seemed to correlate with the sample appearance depicted in Figure 2: treatments that lowered the lipid content (panels B and C vs. panels A and D; panel $G$ vs. panels $E$ and F) may have also reduced the chance of sticking between powder granules. When observed with scanning electron microscopy, granules appeared irregular in shape and size, and no strong conclusions could be drawn for the samples before and after processing with $\mathrm{scCO}_{2}$ or $\mathrm{N}_{2}$ (Figure 3). Therefore, the advantages from $\mathrm{scCO}_{2}$-processed powders include better flowability and a better visual appearance that may attract ingredient buyers and consumers.

In addition, WPC and WPI powders had a reduced creamy, sweet aroma when processed with $\mathrm{scCO}_{2}$. This may have been due to the well-established fact that $\mathrm{scCO}_{2}$ is capable of extracting small nonpolar molecules (Maheshwari et al., 1995). Sensory analyses and characterization of volatile compounds, however, are future research focuses. Nevertheless, whey proteins with a milder aroma and taste may be incorporated in products in which the aroma and flavor of protein ingredients are undesirable, while providing other functionalities of proteins. 

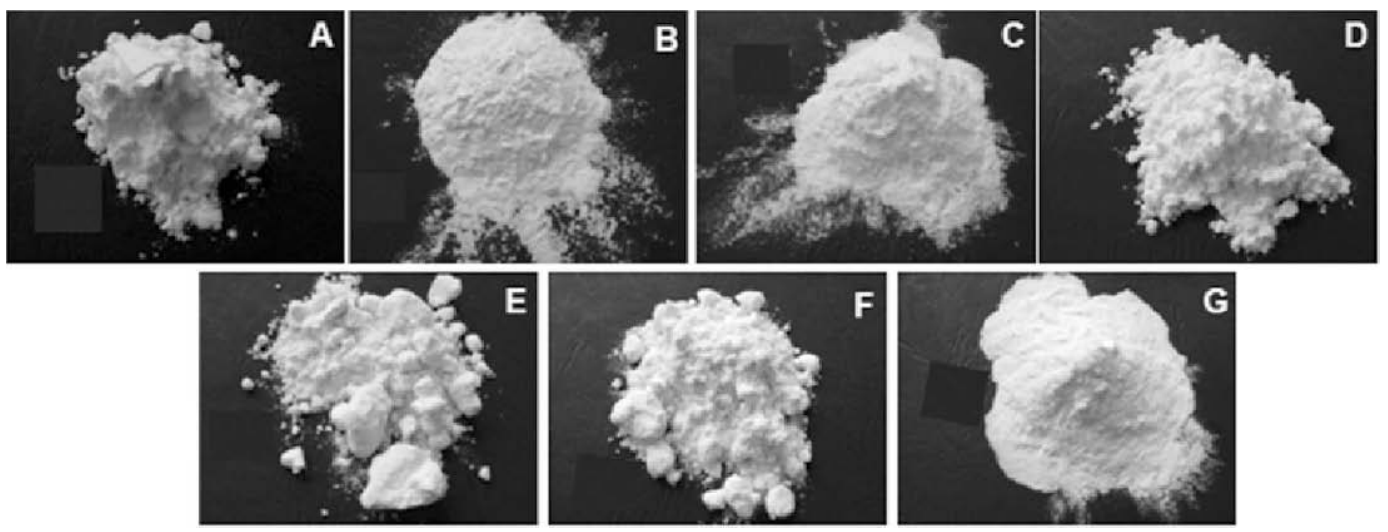

Figure 2. Appearance of powders (5 g) of A) unprocessed whey protein isolate (WPI); B) WPI processed with $\mathrm{CO}_{2}$ at $65^{\circ} \mathrm{C}$ and $10 \mathrm{MPa}$; C) WPI processed with $\mathrm{CO}_{2}$ at $65^{\circ} \mathrm{C}$ and $30 \mathrm{MPa}$; D) WPI processed with $\mathrm{N}_{2}$ at $65^{\circ} \mathrm{C}$ and $10 \mathrm{MPa}$; E) unprocessed whey protein concentrate (WPC); F) WPC processed with $\mathrm{CO}_{2}$ at $65^{\circ} \mathrm{C}$ and $10 \mathrm{MPa}$; and G) WPC processed with $\mathrm{CO}_{2}$ at $65^{\circ} \mathrm{C}$ and $30 \mathrm{MPa}$.

\section{Rheological Data of WPI Solutions Processed by $\mathrm{ScCO}_{2}$ and $\mathrm{N}_{2}$}

For the WPI solution that interacted with $\mathrm{scCO}_{2}$, the sample after resuspending precipitates and adjusting $\mathrm{pH}$ to 3.35 showed a steady development in storage modulus upon heating (Figure 4A), further strengthened during cooling (Figure 4B). Storage modulus $\left(\mathbf{G}^{\prime}\right)$ of the $\mathrm{scCO}_{2}$-processed WPI solution was greater than that of the unprocessed sample and that of the sample processed with $\mathrm{N}_{2}$ under the same conditions (Figure 4). This approach of modifying WPI suspended in solutions was not pursued further because similar results were obtained from $\mathrm{scCO}_{2}$-processed powder samples (Table 2 ), an easier operation that does not present the foaming issue and is easier to scale up. Solutions processed by $\mathrm{scCO}_{2}$ and $\mathrm{N}_{2}$ were not analyzed for composition with the assumption that no significant compositional changes would occur because proteins were dispersed in water. Water evaporation during processing was expected via the container opening due to the continuous gas stream inside the pressure vessel. However, it would be expected that the amount of water evaporated would be similar for $\mathrm{scCO}_{2}$ and $\mathrm{N}_{2}$ treatments. The apparent increase in gel strength for the $\mathrm{scCO}_{2}$-treated solution compared with the controls (unprocessed and that processed by $\mathrm{N}_{2}$ ) may have been caused by the dissolved $\mathrm{scCO}_{2}$ that interacted with proteins, causing irreversible structure changes after $\mathrm{CO}_{2}$ depletion.

Phase-angle changes of WPI solutions during the second step (isothermal at $90^{\circ} \mathrm{C}$ ) where storage modulus developed steadily are plotted in Figure 5 . The tangential function of a phase angle is defined as a ratio of

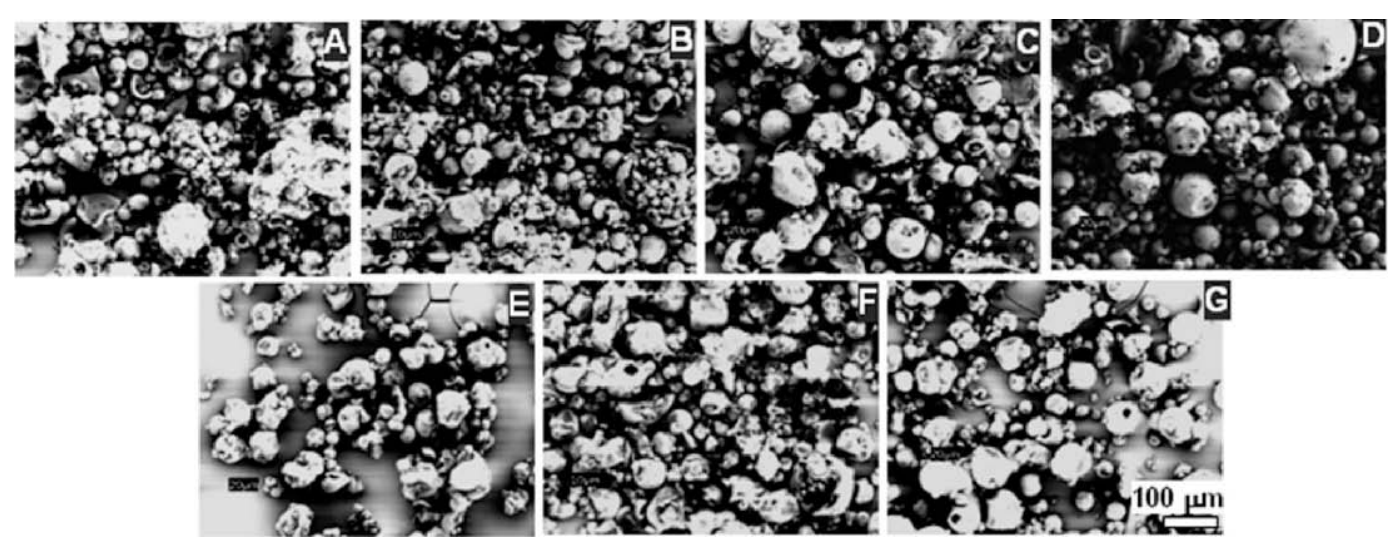

Figure 3. Scanning electron microscopy images for powders of A) unprocessed whey protein isolate (WPI); B) WPI processed with supercritical (sc) $\mathrm{CO}_{2}$ at $65^{\circ} \mathrm{C}$ and $10 \mathrm{MPa}$; C) WPI processed with $\mathrm{scCO}_{2}$ at $65^{\circ} \mathrm{C}$ and $30 \mathrm{MPa} ; \mathrm{D}$ ) WPI processed with $\mathrm{N}_{2}$ at $65^{\circ} \mathrm{C}$ and 10 $\mathrm{MPa}$; E) unprocessed whey protein concentrate (WPC); F) WPC processed with $\mathrm{scCO}_{2}$ at $65^{\circ} \mathrm{C}$ and $10 \mathrm{MPa}$; and G) WPC processed with $\mathrm{scCO}_{2}$ at $65^{\circ} \mathrm{C}$ and $30 \mathrm{MPa}$. Scale bar $=100 \mu \mathrm{m}$. 

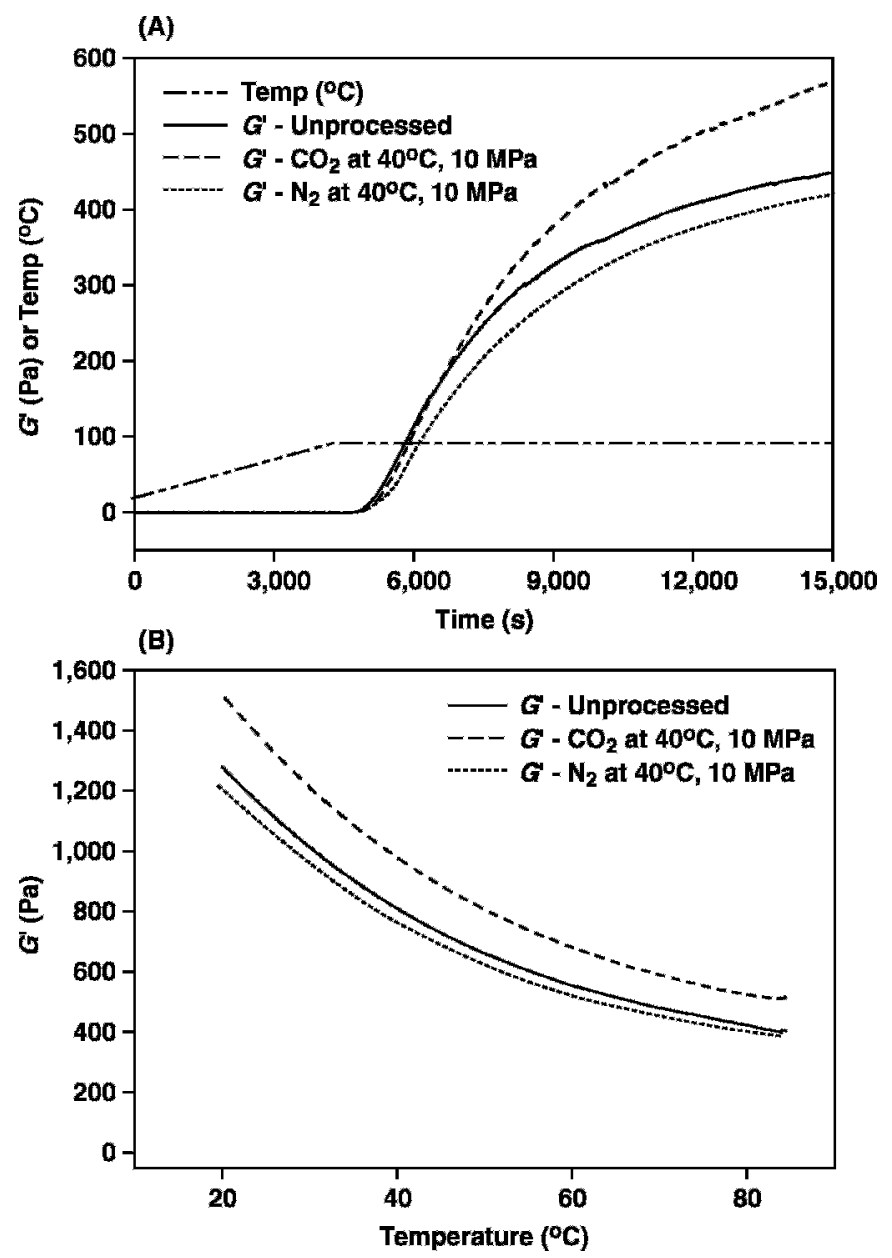

Figure 4. Storage modulus of $9.4 \%$ (wt/vol) whey protein isolate (WPI) solutions ( $\mathrm{pH} 3.35$ ) processed with supercritical $\mathrm{CO}_{2}$ or $\mathrm{N}_{2}$ and unprocessed during (A) heating from 20 to $90^{\circ} \mathrm{C}$ at $1^{\circ} \mathrm{C} / \mathrm{min}$ and holding at $90^{\circ} \mathrm{C}$ for $3 \mathrm{~h}$ and (B) during cooling from 90 to $20^{\circ} \mathrm{C}$ at $1^{\circ} \mathrm{C} / \mathrm{min}$. Data are averages from 3 tests.

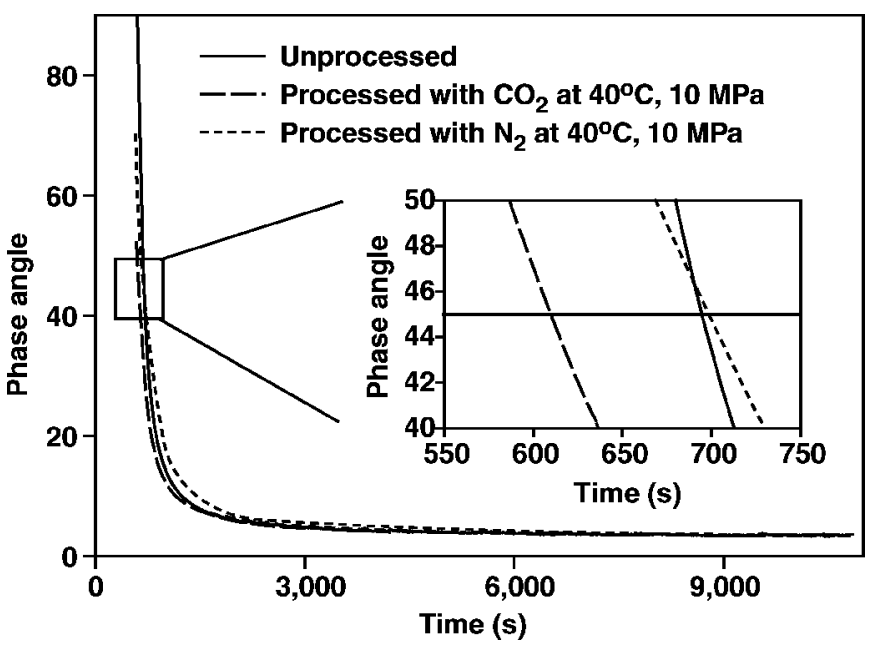

Figure 5. Phase angle of $9.4 \%(\mathrm{wt} / \mathrm{vol})$ whey protein isolate (WPI) solutions ( $\mathrm{pH} 3.35$ ) processed with supercritical $\mathrm{CO}_{2}$ or $\mathrm{N}_{2}$ and unprocessed during holding at $90^{\circ} \mathrm{C}$ for $3 \mathrm{~h}$ after heating from 20 to $90^{\circ} \mathrm{C}$ at $1^{\circ} \mathrm{C} / \mathrm{min}$. Data are averages from 3 tests.

loss $\left(\mathbf{G}^{\prime \prime}\right)$ to storage $\left(\mathrm{G}^{\prime}\right)$ modulus. A phase angle $<45^{\circ}$ indicates a storage modulus that dominates the loss modulus, and a system behaves more elastic- or solidlike. Therefore, the phase angle is a convenient way of monitoring the gelation process and a system with a phase angle $<45^{\circ}$ is commonly referred to as a gel (RossMurphy, 1994). With the assumption that all 3 samples had identical composition, the WPI processed with $\mathrm{scCO}_{2}$ reached a phase angle of $45^{\circ}$ (i.e., gelation) faster than the unprocessed WPI and that processed with $\mathrm{N}_{2}$ (insert in Figure 5). The latter 2 samples had an almost identical gelation time. The differences in gelation time further indicated that the dissolved $\mathrm{CO}_{2}$ changed whey protein structures $\left(\mathrm{CO}_{2}\right.$ has a much greater solubility in water than does $\mathrm{N}_{2}$ ), which enabled a faster gelation and a stronger gel. Both computer simulations (of lysozyme) and experiments (from films of albumin and lyso-

Table 2. Storage modulus $\left(\mathrm{G}^{\prime}\right)^{1}$ of whey protein isolate (WPI) or whey protein concentrate (WPC) samples $(9.9 \%$, wt/vol, at $\mathrm{pH} 7.0 ; 9.4 \%$, wt/vol, at $\mathrm{pH}$ 3.35) unprocessed and processed with supercritical $\mathrm{CO}_{2}\left(\mathrm{scCO}_{2}\right)$ or $\mathrm{N}_{2}$

\begin{tabular}{|c|c|c|c|c|c|c|}
\hline Sample & $\begin{array}{c}\text { Temperature } \\
\left({ }^{\circ} \mathrm{C}\right)\end{array}$ & $\begin{array}{l}\text { Pressure } \\
(\mathrm{MPa})\end{array}$ & \multicolumn{2}{|c|}{$\mathrm{G}^{\prime}(\mathrm{Pa})$ after step $(2)$ at $90^{\circ} \mathrm{C}$} & \multicolumn{2}{|c|}{$\mathrm{G}^{\prime}(\mathrm{Pa})$ after step (4) at $20^{\circ} \mathrm{C}$} \\
\hline Unprocessed WPI & - & - & $449 \pm 19^{c}$ & $6,198 \pm 66^{\mathrm{a}}$ & $1,279 \pm 31^{\mathrm{b}}$ & $19,197 \pm 138^{\mathrm{a}}$ \\
\hline $\mathrm{N}_{2}$-processed WPI solution & 65 & 30 & $421 \pm 14^{\mathrm{c}}$ & - & $1,200 \pm 16^{b}$ & - \\
\hline $\mathrm{scCO}_{2}$-processed WPI powder & 65 & 10 & $526 \pm 25^{\mathrm{a}}$ & $6,262 \pm 11^{\mathrm{a}}$ & $1,518 \pm 20^{\mathrm{a}}$ & $21,130 \pm 132^{\mathrm{a}}$ \\
\hline $\mathrm{scCO}_{2}$-processed WPI powder & 65 & 30 & $508 \pm 13^{\mathrm{b}}$ & $6,599 \pm 47^{a}$ & $1,519 \pm 30^{\mathrm{a}}$ & $20,590 \pm 355^{\mathrm{a}}$ \\
\hline $\mathrm{scCO}_{2}$-processed WPC powder & 65 & 10 & $75 \pm 7^{\mathrm{e}}$ & $397 \pm 7^{\mathrm{bc}}$ & $314 \pm 14^{\mathrm{d}}$ & $2,253 \pm 16^{b c}$ \\
\hline $\mathrm{scCO}_{2}$-processed WPC powder & 65 & 30 & $113 \pm 12^{\mathrm{d}}$ & $443 \pm 15^{\mathrm{b}}$ & $405 \pm 13^{\mathrm{c}}$ & $2,603 \pm 37^{\mathrm{b}}$ \\
\hline
\end{tabular}

${ }^{\mathrm{a}-\mathrm{e}}$ Means with a different superscript letter within a column are statistically different.

${ }^{1}$ Results are averages $\pm 95 \%$ confidence intervals from 3 tests. 


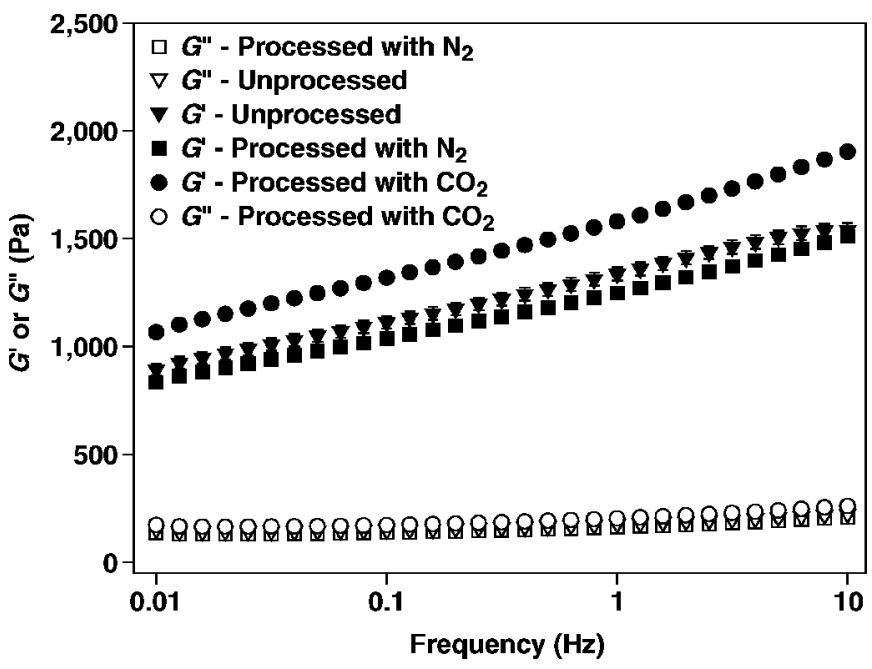

Figure 6. Mechanical spectra of 9.4\% (wt/vol) whey protein isolate (WPI) solutions ( $\mathrm{pH} 3.35$ ) processed with supercritical $\mathrm{CO}_{2}$ or $\mathrm{N}_{2}$ and unprocessed after cooling to $20^{\circ} \mathrm{C}$. Data are averages from 3 tests and error bars are $95 \%$ confidence intervals. $\mathrm{G}^{\prime}=$ storage modulus; $\mathrm{G}^{\prime \prime}=$ loss modulus.

zyme) have shown that $\mathrm{scCO}_{2}$ alternates the secondary structure (the relative amount of $\alpha$-helix, $\beta$-sheet, and random coil) of proteins (Striolo et al., 2003; Liu et al., 2004). Further studies are needed to illustrate the exact mechanisms of whey protein molecular structure changes induced by $\mathrm{CO}_{2}$ and how these changes correlate with rheological properties.

Frequency sweep tests during step 3 (at $90^{\circ} \mathrm{C}$ ) and step 5 (at $20^{\circ} \mathrm{C}$ ) showed that $\mathrm{G}^{\prime}$ was much greater than $\mathrm{G}^{\prime \prime}$, exemplified in Figure 6 from step 5, indicating that all samples formed weak gels. Data suggested that the gel formed from the $\mathrm{CO}_{2}$-treated WPI was statistically stronger than the other 2 samples $(P<0.05)$.

\section{Rheological Data of WPI Powders Processed by $\mathrm{scCO}_{2}$ and $\mathrm{N}_{2}$}

Comparing thermal gelation properties, WPI powders processed by $\mathrm{scCO}_{2}$ formed a stronger gel (higher $\mathrm{G}^{\prime}$ ) than those unprocessed or processed by $\mathrm{N}_{2}$ (Figure 7). During the heating and holding steps, the sample extracted by $\mathrm{scCO}_{2}$ at $65^{\circ} \mathrm{C}$ and $10 \mathrm{MPa}$ formed the strongest gel, whereas that extracted by $\mathrm{scCO}_{2}$ at $65^{\circ} \mathrm{C}$ and $30 \mathrm{MPa}$ was slightly weaker (Figure $7 \mathrm{~A}$ ). Upon cooling (Figure 7B), the $2 \mathrm{scCO}_{2}$-treated samples had an almost identical gel strength. Comparing the compositions of $2 \mathrm{scCO}_{2}$-processed samples (Table 1), there was no statistical difference in protein content, which might have led to a similar gel strength after cooling.

The sample processed by $\mathrm{scCO}_{2}$ at $30 \mathrm{MPa}$ showed a much faster gelation (a shorter time to reach a phase
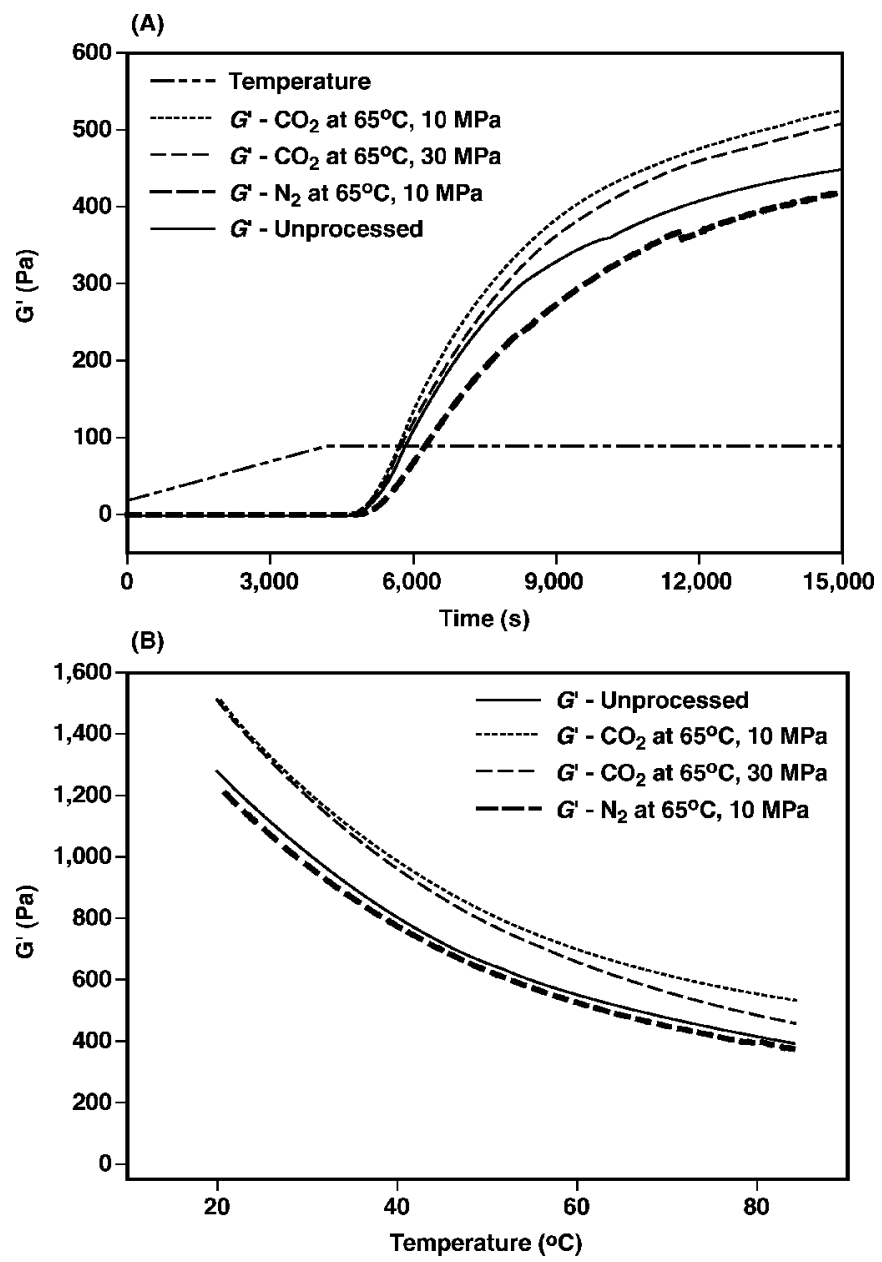

Figure 7. Storage modulus $\left(\mathrm{G}^{\prime}\right)$ of $9.4 \%$ (wt/vol) whey protein isolate (WPI) solutions ( $\mathrm{pH}$ 3.35) constituted from powders processed with supercritical $\mathrm{CO}_{2}$ or $\mathrm{N}_{2}$ and that unprocessed during (A) heating from 20 to $90^{\circ} \mathrm{C}$ at $1^{\circ} \mathrm{C} / \mathrm{min}$ and holding at $90^{\circ} \mathrm{C}$ for $3 \mathrm{~h}$ and (B) cooling from 90 to $20^{\circ} \mathrm{C}$ at $1^{\circ} \mathrm{C} / \mathrm{min}$. Data are averages from 3 tests.

angle of $45^{\circ}$ ) than the other 3 samples (Figure 8 ). The gelation time for the unprocessed sample was similar to that of samples processed by $\mathrm{scCO}_{2}$ at $10 \mathrm{MPa}$ and shorter than for samples processed by $\mathrm{N}_{2}$. The gelation times correlated well with protein content $\left(\mathrm{R}^{2}=0.95\right)$ and lipid content $\left(\mathrm{R}^{2}=0.98\right)$ but not with moisture content $\left(R^{2}=0.65\right)$.

The time to reach a phase angle of $45^{\circ}$ correlated with observations from the "salting out" of proteins (Figure 9). The WPI powder after $\mathrm{scCO}_{2}$ processing at $65^{\circ} \mathrm{C}$ and $30 \mathrm{MPa}$ had the greatest soluble protein content after precipitation by ammonium sulfate, indicating that the sample had the lowest surface hydrophocity. This lowered surface hydrophobicity, possibly due to removal of bound lipids (Table 1), may have induced the faster gelation. There was no difference in surface hydrophobicity for the unprocessed sample and that 


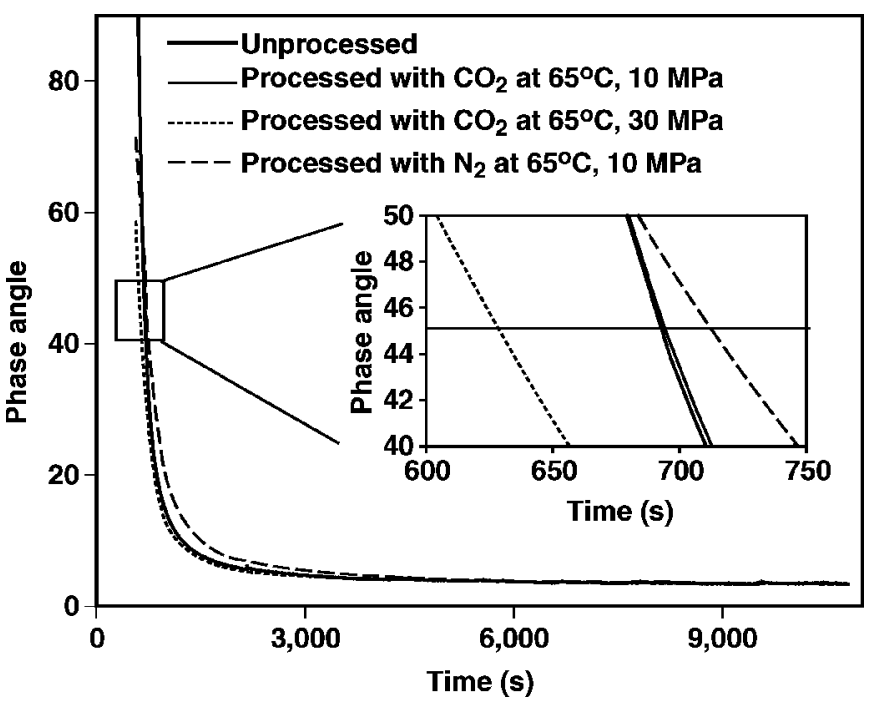

Figure 8. Phase angle of $9.4 \%(\mathrm{wt} / \mathrm{vol})$ whey protein isolate (WPI) solutions ( $\mathrm{pH}$ 3.35) constituted from powders processed with supercritical $\mathrm{CO}_{2}$ or $\mathrm{N}_{2}$ and that unprocessed during holding at $90^{\circ} \mathrm{C}$ for $3 \mathrm{~h}$ after heating from 20 to $90^{\circ} \mathrm{C}$ at $1^{\circ} \mathrm{C} / \mathrm{min}$. Data are averages from 3 tests.

processed by $\mathrm{scCO}_{2}$ at $65^{\circ} \mathrm{C}$ and $10 \mathrm{MPa}$ (Figure 9), which correlated with no difference in the gelation time for these 2 samples (Figure 8). Conversely, the sample processed by $\mathrm{N}_{2}$ had the poorest protein solubility during precipitation (Figure 9), which is reflected by the longest gelation time of this sample (Figure 8). It seemed that surface hydrophobicity may have contributed to the observed differences in gelation kinetics. Eventually, if the sample is allowed enough time to

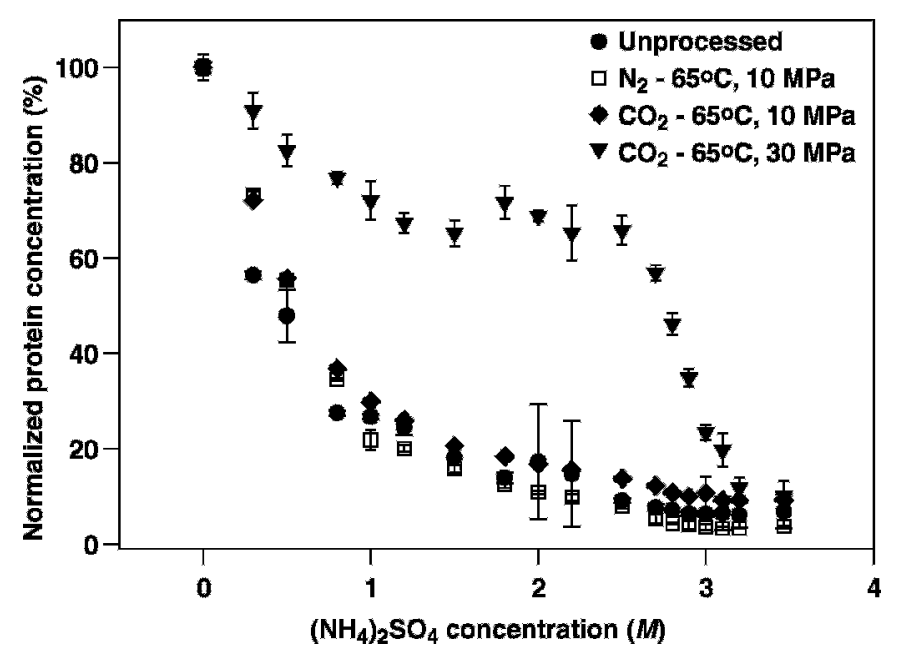

Figure 9. Salting-out of whey protein isolate (WPI) samples at $\mathrm{pH}$ 3.35 by different concentrations of ammonium sulfate. The remaining soluble protein concentrations are normalized to that at $0 \mathrm{M}$ ammonium sulfate. form chemical and physical bonds, the total protein concentration (Table 1) may be a critical factor determing the final gel strength (Table 2, Figure 7), because heating denatures whey proteins before formation of the bonds.

Storage moduli of samples following rheological test steps 2 and 4 are compiled in Table 2 . When correlating compositions in Table 1 and $\mathrm{G}^{\prime}$ data in Table 2, protein contents correlated much better with rheological data at $\mathrm{pH} 3.35\left(\mathrm{R}^{2}=0.89\right.$ for $\mathrm{G}^{\prime}$ after step 2 and 0.94 for $\mathrm{G}^{\prime}$ after step 4) than lipid and moisture contents (all $\mathrm{R}^{2}<0.77$ ). The unprocessed sample and that processed by $\mathrm{N}_{2}$ showed no statistical difference in $\mathrm{G}^{\prime}$, whereas the $\mathrm{scCO}_{2}$-processed samples formed gels with similar strength. It is also interesting to note that there was no statistical difference in gel strength for the $\mathrm{scCO}_{2}$ treatment of WPI in either powder form or dispersed in water. However, to judge whether the same interactions between protein and $\mathrm{scCO}_{2}$ occurred for the solution and powder treatments, detailed information of composition, surface hydrophobicity, secondary (possibly tertiary) structures of proteins, and interactions between proteins and lipids is needed.

Storage moduli of samples at $\mathrm{pH} 7.0$ and $0.1 \mathrm{M} \mathrm{NaCl}$ were much greater than the corresponding sample at pH 3.35 (Table 2). Enhanced gel strength was also observed for $\mathrm{scCO}_{2}$-processed WPI at $\mathrm{pH}$ 7.0, but the increase was not statistically significant. Ikeda et al. (1999) studied whey protein gelation with different $\mathrm{NaCl}$ concentrations at $\mathrm{pH} 7.0$ and observed the strongest gel at $0.1 \mathrm{M} \mathrm{NaCl}$. Therefore, the addition of $0.1 \mathrm{M}$ $\mathrm{NaCl}$ to the WPI sample may have lessened the enhanced gel strength due to $\mathrm{scCO}_{2}$ processing.

\section{Rheological Data of WPC Powders Processed by $\mathrm{scCO}_{2}$}

Compared with the unprocessed sample, the WPC powders processed by $\mathrm{scCO}_{2}$ formed a gel with a much greater storage modulus (Figure 10), with the $30 \mathrm{MPa}$ treatment being more significant than the $10 \mathrm{MPa}$ treatment. Table 1 shows statistical differences of protein content among all samples, but only the $30 \mathrm{MPa}$ treatment lowered the lipids content. The enhanced gelling properties may have been induced by compositional changes and the interaction between $\mathrm{scCO}_{2}$ and lipid-bound protein in WPC. Greater lipid content in WPC compared with WPI signified the enhancement in gelation properties by $\mathrm{scCO}_{2}$ treatments.

When comparing phase-angle changes of WPC samples during step 2, the gelation time followed a decreasing order of $30 \mathrm{MPa}$ treatment, $10 \mathrm{MPa}$ treatment, and untreated sample (Figure 11). Storage modulus data after test steps 2 and 4 are summarized in Table 2. At 

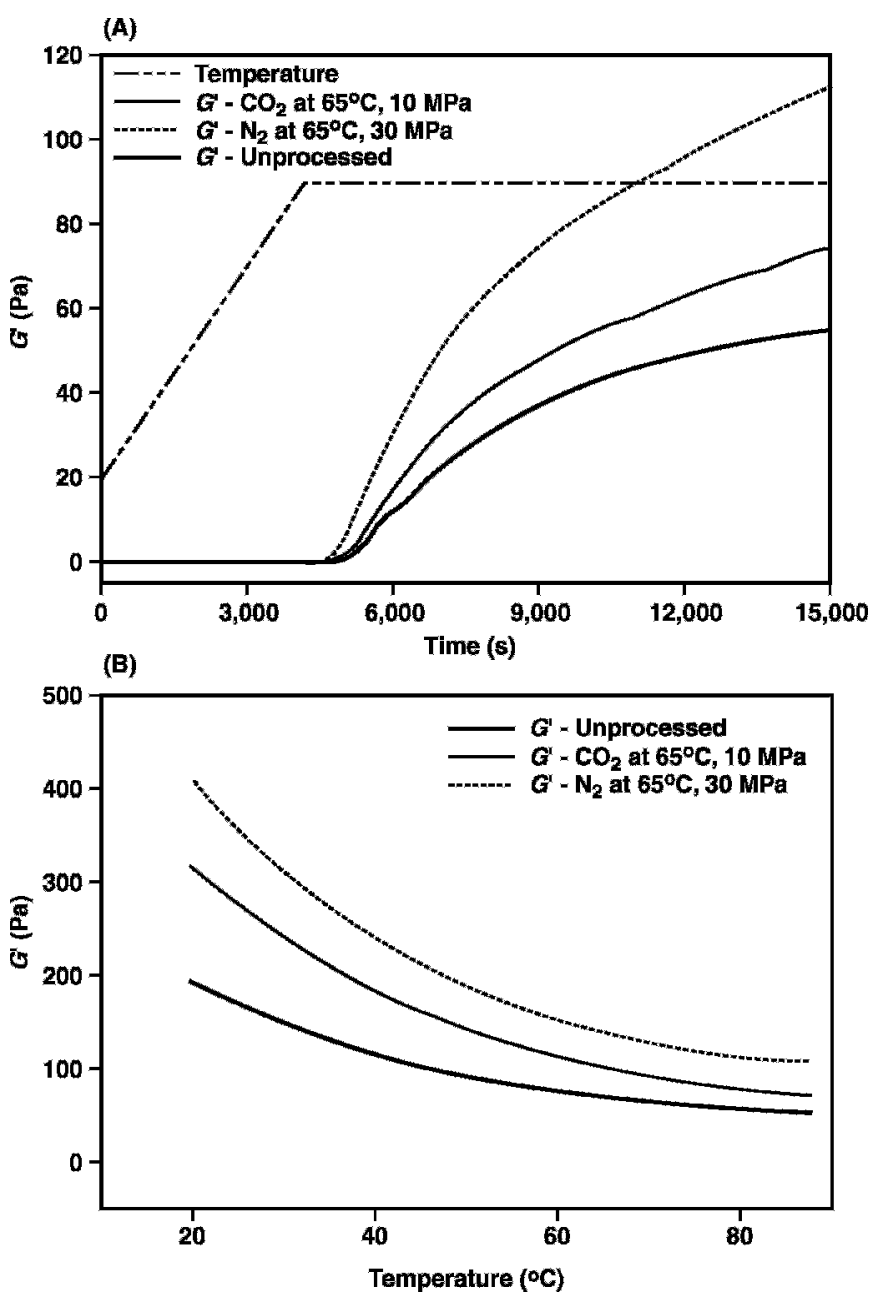

Figure 10. Storage modulus $\left(\mathrm{G}^{\prime}\right)$ of $9.4 \%(\mathrm{wt} / \mathrm{vol})$ whey protein concentrate (WPC) solutions ( $\mathrm{pH} 3.35$ ) constituted from powders processed with supercritical $\mathrm{CO}_{2}$ and that unprocessed during (A) heating from 20 to $90^{\circ} \mathrm{C}$ at $1^{\circ} \mathrm{C} / \mathrm{min}$ and holding at $90^{\circ} \mathrm{C}$ for $3 \mathrm{~h}$ and (B) cooling from 90 to $20^{\circ} \mathrm{C}$ at $1^{\circ} \mathrm{C} / \mathrm{min}$. Data are averages from 3 tests.

$\mathrm{pH} 3.35, \mathrm{G}^{\prime}$ increased from 55 to $75 \mathrm{~Pa}$ for the $10 \mathrm{MPa}$ treatment and to $113 \mathrm{~Pa}$ for the $30 \mathrm{MPa}$ treatment after step 2; after step 4, $\mathrm{G}^{\prime}$ increased from 190 to $314 \mathrm{~Pa}$ for the $10 \mathrm{MPa}$ treatment and to $405 \mathrm{~Pa}$ for the $30 \mathrm{MPa}$ treatment. Similar to WPI, protein contents correlated much better with rheological data at $\mathrm{pH} 3.35\left(\mathrm{R}^{2}=1.00\right.$ for $G^{\prime}$ after step 2 and 0.95 for $G^{\prime}$ after step 4) than did lipid and moisture contents (all $\mathrm{R}^{2}<0.81$ ). The improvement in the relative gel strength after $\mathrm{scCO}_{2}$ processing was less significant at $\mathrm{pH}$ 7.0: $\mathrm{G}^{\prime}$ increased from 334 to $397 \mathrm{~Pa}$ for the $10 \mathrm{MPa}$ treatment and to $443 \mathrm{~Pa}$ for the $30 \mathrm{MPa}$ treatment after step 2; and $\mathrm{G}^{\prime}$ increased from 2,025 to 2,253 $\mathrm{Pa}$ for the $10 \mathrm{MPa}$ treatment and to 2,603 $\mathrm{Pa}$ for the $30 \mathrm{MPa}$ treatment after step 4. Similar to $\mathrm{pH} 3.35$, protein contents correlated much better with rheological data at $\mathrm{pH} 7.0\left(\mathrm{R}^{2}=\right.$

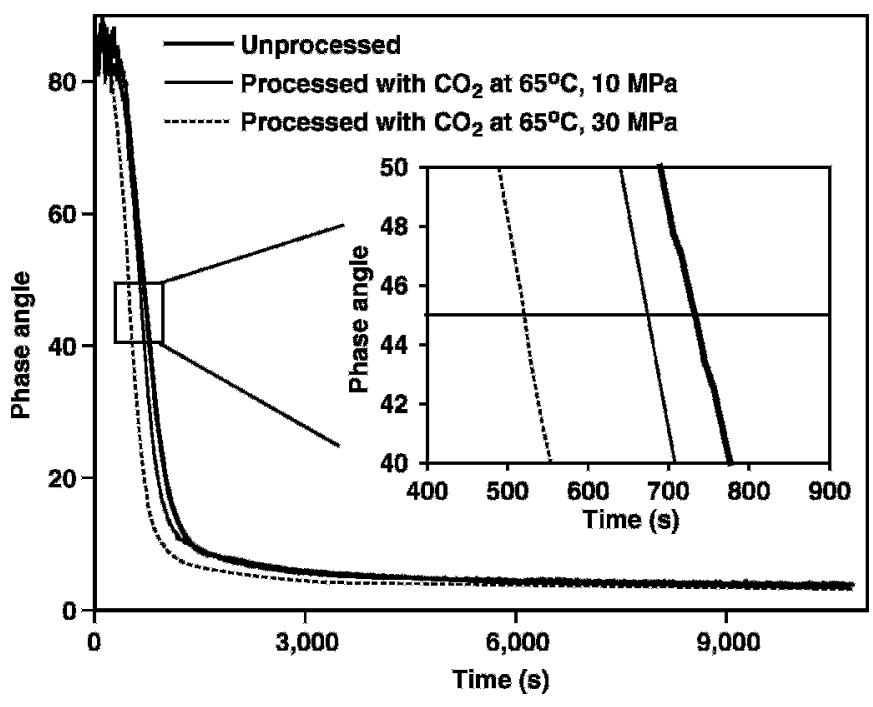

Figure 11. Phase angle of $9.4 \%$ (wt/vol) whey protein concentrate (WPC) solutions ( $\mathrm{pH} 3.35$ ) constituted from powders processed with supercritical $\mathrm{CO}_{2}$ and unprocessed during holding at $90^{\circ} \mathrm{C}$ for $3 \mathrm{~h}$ after heating from 20 to $90^{\circ} \mathrm{C}$ at $1^{\circ} \mathrm{C} / \mathrm{min}$. Data are averages from 3 tests.

0.95 for $\mathrm{G}^{\prime}$ after step 2 and 1.00 for $\mathrm{G}^{\prime}$ after step 4) compared with lipid and moisture contents (all $\mathrm{R}^{2}<$ $0.81)$.

In summary, gelling properties of whey proteins, either dissolved in water or in powder form, can be improved after $\mathrm{scCO}_{2}$ processing. Compositional and surface hydrophobicity analyses indicated that rheological properties were affected not only by composition (particularly protein content), but also by structural changes due to the $\mathrm{scCO}_{2}$ treatment. Removal of lipids from WPC was incomplete and may be improved further under other conditions, making $\mathrm{scCO}_{2}$ a low-cost purification technique compared with those based on membrane filtrations or chromatography. We expect that compositional and structural changes will also significantly change interfacial properties of proteins; this aspect will be studied in the near future. We are currently extending extraction conditions and characterizing the corresponding functionality changes over a broader range of testing conditions and techniques, with a goal of establishing correlations between extraction, composition, and structure and functionalities of whey proteins.

\section{ACKNOWLEDGMENTS}

This project was supported by the Tennessee Agricultural Experiment Station Hatch project and UTIA Idea Grant. Discussions with Allen Foegeding, Jochen Weiss, and Jack Davis are highly appreciated. 


\section{REFERENCES}

Alavi, S. H., B. K. Gogoi, M. Khan, B. J. Bowman, and S. S. H. Rizvi. 1999. Structural properties of protein-stabilized starch-based supercritical fluid extrudates. Food Res. Int. 32:107-118.

AOAC. 1990. Official Methods of Analysis. 15th ed. AOAC, Arlington, VA.

Baier, S. K., and D. J. McClements. 2005. Influence of cosolvent systems on the gelation mechanism of globular protein: Thermodynamic, kinetic, and structural aspects of globular protein gelation Comp. Rev. Food Sci. Food Safety 4:43-54.

Bradford, M. M. 1976. A rapid and sensitive method for the quantification of microgram quantities of protein utilizing the principle of protein-dye binding. Anal. Biochem. 72:248-254

Damodaran, S. 1997. Food proteins: An overview. Pages 1-21 in Food Proteins and Their Application. S. Damodaran and A. Paraf, ed. Marcel Dekker, New York, NY.

Dickinson, E., and V. B. Galazka. 1991. Emulsion stabilization by ionic and covalent complexes of beta-lactoglobulin with polysaccharides. Food Hydrocoll. 5:281-296.

Dickinson, E., and M. G. Semenova. 1992. Emulsifying properties of covalent protein dextran hybrids. Colloids Surf. 64:299-310.

Foegeding, E. A., J. P. Davis, D. Doucet, and M. K. McGuffey. 2002. Advances in modifying and understanding whey protein functionality. Trends Food Sci. Technol. 13:151-159.

Froning, G. W., R. L. Wehling, S. L. Cuppett, M. M. Pierce, L. Niemann, and D. K. Siekman. 1990. Extraction of cholesterol and other lipids from dried egg yolk using supercritical carbon dioxide. J. Food Sci. 55:95-98.

Gogoi, B. K., S. H. Alavi, and S. S. H. Rizvi. 2000. Mechanical properties of protein-stabilized starch-based supercritical fluid extrudates. Int. J. Food Prop. 3:37-58.

Hofland, G. W., M. van Es, L. A. M. van der Wielen, and G. J. Witkamp. 1999. Isoelectric precipitation of casein using high-pressure $\mathrm{CO}_{2}$. Ind. Eng. Chem. Res. 38:4919-4927.

Ikeda, S., E. A. Foegeding, and T. Hagiwara. 1999. Rheological study on the fractal nature of the protein gel structure. Langmuir 15:8584-8589.

Ju, Z. Y., N. Hettiarachchy, and A. Kilara. 1999. Thermal properties of whey protein aggregates. J. Dairy Sci. 82:1882-1889.

Lin, V. J. C., and J. L. Koenig. 1976. Raman studies of bovine serum albumin. Biopolymers 15:203-218.

Lindahl, M., A. Faris, T. Wadstrom, and S. Hjerten. 1981. A new test based on "salting out" to measure relative surface hydrophobicity of bacterial cells. Biochim. Biophys. Acta 677:471-476.

Liu, H. L., W. C. Hsieh, and H. S. Liu. 2004. Molecular dynamics simulations to determine the effect of supercritical carbon dioxide on the structural integrity of hen egg white lysozyme. Biotechnol. Prog. 20:930-938.

Maheshwari, P., E. T. Ooi, and Z. L. Nikolov. 1995. Off-flavor removal from soy-protein isolate by using liquid and supercritical carbon dioxide. J. Am. Oil Chem. Soc. 72:1107-1115.

Manganiello, L., A. Ríos, and V. Valcárcel. 2000. Automatic microgravimetric determination of fats in milk products by use of supercritical fluid extraction with on-line piezoelectric detection. J. Chromatogr. A. 874:265-274.

McClements, D. J. 2005. Food Emulsions: Principles, Practices, and Techniques. 2nd ed. CRC Press, Boca Raton, FL.

McHugh, M. A., and V. J. Krukonis. 1994. Supercritical Fluid Extraction: Principles and Practice. 2nd ed. Butterworth-Heinemann, Boston, MA.
Molina, E., A. Papadopoulou, and D. A. Ledward. 2001. Emulsifying properties of high pressure treated soy protein isolate and 7S and 11 Slobulins. Food Hydrocoll. 15:263-269.

Resch, J. J., C. R. Daubert, and E. A. Foegeding. 2005. The effects of acidulant type on the rheological properties of beta-lactoglobulin gels and powders derived from these gels. Food Hydrocoll. 19:851-860.

Ross-Murphy, S. B. 1994. Rheological Methods. Page 343 in Physical Techniques for the Study of Food Biopolymers. S. B. Ross-Murphy, ed. Blackie Academic \& Professional, London, UK.

Strange, E. D., R. P. Konstance, P. M. Tomasula, D. L. van Hekken, P. W. Smith, T. R. Boswell, D. P. Lu, and V. H. Holsinger. 1998. Functionality of casein precipitated by carbon dioxide. J. Dairy Sci. 81:1517-1524.

Striolo, A., A. Favaro, N. Elvassore, A. Bertucco, and V. Di Noto. 2003. Evidence of conformational changes for protein films exposed to high-pressure $\mathrm{CO}_{2}$ by FT-IR spectorscopy. J. Supercrit. Fluid. 27:283-295.

Tanaka, N., A. Koyasu, I. Kobayashi, and S. Kunugi. 1996a. Pressureinduced change in proteins studied through chemical modifications. Int. J. Biol. Macromol. 18:275-280.

Tanaka, N., and S. Kunugi. 1996. effect of pressure on the denaturation exchange reaction of alpha-lactalbumin and beta-lactoglobulin. Int. J. Biol. Macromol. 18:33-39.

Tanaka, N., Y. Tsurui, I. Kobayashi, and S. Kunugi. 1996b. The pressure-induced structural change of bovine alpha-lactabumin as studied by fluorescence hydrophobic probe. Int. J. Pept. Protein Res. 48:259-264

Thiering, R., G. Hofland, N. Foster, G. J. Witkamp, and L. van de Wielen. 2001a. Carbon dioxide induced soybean protein precipitation: Protein fractionation, particle aggregation, and continuous operation. Biotechnol. Prog. 17:513-521.

Thiering, R., G. Hofland, N. Foster, G. J. Witkamp, and L. van de Wielen. 2001b. Fractionation of soybean proteins with pressurized carbon dioxide as a volatile electrolyte. Biotechnol. Bioeng. $73: 1-11$

Tomasula, P. M., J. C. Craig, and R. T. Boswell. 1997. A continuous process for casein production using high-pressure carbon dioxide. J. Food Eng. 33:405-419.

Tomasula, P. M., N. Parris, R. T. Boswell, and R. O. Moten. 1998. Preparation of enriched fractions of alpha-lactalbumin and betalactoglobulin from cheese whey using carbon dioxide. J. Food Process. Pres. 22:463-476.

Tomasula, P. M., and W. C. F. Yee. 2001. Enriched fractions of alphalactalbumin (alpha-LA) and beta-lactoglobulin (beta-LG) from whey protein concentrate using carbon dioxide. Functional properties in aqueous solution. J. Food Process. Pres. 25:267-282.

van Vliet, T., A. H. Martin, and M. A. Bos. 2002. Gelation and interfacial behavior of vegetable proteins. Curr. Opin. Colloid Interf. Sci. 7:462-468.

Verheul, M., and S. P. F. M. Roefs. 1998. Structure of particulate whey protein gels: Effect of $\mathrm{NaCl}$ concentration, $\mathrm{pH}$, heating temperature, and protein composition J. Agric. Food Chem. 46:4909-4916.

Wolf, W. R., D. E. LaCroix, R. Goel, and M. Kaur. 2003. Total fat analysis in milk- and soy-based infant formula powder by supercritical fluid extraction. J. Am. Oil Chem. Soc. 80:853-857.

Zhang, J., S. Burrows, C. Gleason, M. A. Matthews, M. J. Drews, M. LaBerge, and Y. H. An. 2006. Sterilization of Bacillus pumilus spores using supercritical carbon dioxide. J. Microbiol. Meth. $66: 479-485$. 